\title{
Backcross Hybrids of Zinnia angustifolia and Z. violacea: Embryology, Morphology, and Fertility
}

\author{
Thomas H. Boyle ${ }^{1}$ \\ Department of Plant and Soil Sciences, French Hall, University of Massachusetts, Amherst, MA 01003
}

Additional index words. interspecific hybridization, ornamental plants, Zinnia marylandica

\begin{abstract}
True-breeding lines of Zinnia marylandica Spooner, Stimart and Boyle [allotetraploids of Z. angustifolia H.B.K. and $Z$. violacea Cav. $(2 \mathrm{n}=46)]$ were reciprocally backcrossed with diploid and autotetraploid forms of $Z$. angustifolia (2n $=22$ or 44$)$ and $Z$. violacea $(2 n=24$ or 48$)$. In most cases, backcrosses were more successful with $Z$. angustifolia and $Z$. violacea as autotetraploids than as diploids. Seed-generated, backcross $\left(\mathrm{BC}_{1}\right)$ families were obtained by crossing $Z$. marylandica (as female) with autotetraploid $Z$. angustifolia or autotetraploid $Z$. violacea. $\mathrm{BC}_{1}$ plants were phenotypically intermediate between the two parental lines for most morphological characters. Crosses between $Z$. marylandica and autotetraploid $Z$. angustifolia yielded $\mathrm{BC}_{1}$ plants with $33 \%$ stainable pollen, whereas crosses between $Z$. marylandica and autotetraploid $Z$. violacea yielded $\mathrm{BC}_{1}$ plants that produced malformed, poorly-stained pollen. No embryos were observed in capitula collected from field-grown $\mathrm{BC}_{1}$ plants. $\mathrm{BC}_{1}$ hybrids of $Z$. marylandica and autotetraploid $Z$. violacea produced larger capitula and more ray florets than $Z$. marylandica, and exhibited novel combinations of floral pigments not observed in $Z$. marylandica ray florets. $\mathrm{BC}_{1}$ hybrids of $Z$. marylandica and $Z$. violacea have commercial potential as seed-propagated, bedding plants.
\end{abstract}

The common zinnia [Zinnia violacea (McVaugh, 1984); formerly Z. elegans Jacq. (Tomes, 1963)] is a popular bedding plant and cut flower that exhibits considerable phenotypic diversity for plant habit and ray floret color and morphology. Commercial cultivars of $\mathrm{Z}$. violacea, however, are subject to attack by three major pathogens: Altemaria zinniae Pape (alternaria blight), Erysiphe cichoracearum DC. ex Merat (powdery mildew), and Xanthomonas campestris pv. zinniae Hopkins and Dowson (bacterial leaf and flower spot) (Andersen, 1971; Jones and Strider, 1979; Lipschutz, 1965; Tomes, 1963). These pathogens incite moderate to severe epiphytotics within Z violacea plantings, resulting in plant losses and/or decreased ornamental value. The narrow-leaved zinnia [Z. angustifolia (McVaugh, 1984)] is highly resistant to these pathogens (Andersen, 1971; Jones and Strider, 1979; Lipschutz, 1965; Torres, 1963), and is a promising source of disease resistance for Zinnia breeding programs.

Crosses between Z. angustifolia $(2 n=2 x=22)$ and Z. violacea $(2 n$ $=2 x=24$ ) yield infertile allodiploids $(2 n=2 x=23)$ (Boyle and Stimart, 1982; Terry-Lewandowski et al., 1984). Colchicine-induced allotetraploids $(2 n=4 x=46)$ exhibit preferential pairing of homologous chromosomes and infrequent pairing of homoeologous chromosomes, and, as a consequence, are partially fertile and breed true from seed (Terry-Lewandowski et al., 1984). Allotetraploids of Z. angustifolia and $Z$. violacea, collectively known as $Z$. marylandica (Spooner et al., 1991), exhibit high levels of resistance to A. zinniae and E. cichoracearum and moderate to high levels of resistance to $\mathrm{X}$. campestris pv. Zinniae (Terry-Lewandowski and Stimart, 1983).

To obtain the expression of new characters, it would be desirable to backcross $Z$. marylandica to the parental species. The objectives of this study were to determine the pathways of backcrossing $\mathrm{Z}$. marylandica to $Z$. angustifolia and $Z$. violacea, and to examine the morphology and fertility of the $\mathrm{BC}_{1}$ plants and uniformity within $\mathrm{BC}_{1}$ families.

\footnotetext{
Received for publication 12 June 1995. Accepted for publication 31 Aug. 1995 Publication no. 3162 of the Massachusetts Agricultural Experiment Station. I acknowledge partial support of this investigation by a grant awarded by The Fred C. Gloeckner Foundation, Inc. The cost of publishing this paper was defrayed in part by the payment of page charges. Under postal regulations, this paper therefore must be hereby marked advertisement solely to indicate this fact. 'Associate professor.
}

\section{Materials and Methods}

Plant material. Table 1 lists the accessions of $Z$. angustfolia, $Z$. violacea, and Z. marylandica that were used for study. Autotetraploid clones of Z. angustifolia 'Linearis White' were obtained by treating lateral buds with colchicine (Boyle and Stimart, 1982); the clones were propagated asexually and intercrossed to create line A88C. Two plants of Z. violacea 'State Fair' $(2 n=4 x=48)$ were crossed reciprocally and their progeny sib-crossed for two generations; the resulting line (V86C) was true-breeding for yellow ray florets and exhibited more phenotypic uniformity than the original cultivar. Zinnia marylandica line M1C was produced by crossing $Z$. angustifolia 'Linearis White' (as female) with $Z$. violacea 'Thumbelina Mini-Pink'; line M2C was produced by crossing Z. angustifolia 'Linearis White' (as female) with Z. violacea 'Crimson Monarch'. Procedures used for interspecific hybridization were described previously (Boyle and Stimart, 1982). One interspecific hybrid seedling in each $\mathrm{F}_{1}$ population was clonally propagated by rooting terminal shoot cuttings. Fertile allotetraploid shoots were recovered after treating lateral buds with colchicine (Boyle and Stimart, 1982). Seeds were harvested from selfed florets, and were bulked. Lines M1C and M2C bred true-to-type in subsequent

Table 1. Zinnia accessions used as parental material, and their chromosome numbers, genomic formulas, and sources.

\begin{tabular}{|c|c|c|c|c|}
\hline \multirow[b]{2}{*}{ Taxon } & \multicolumn{4}{|c|}{ Chromosome } \\
\hline & Cultivar or line & $\begin{array}{l}\text { no. } \\
(2 n)\end{array}$ & $\begin{array}{l}\text { Genomic } \\
\text { formula }\end{array}$ & Source ${ }^{y}$ \\
\hline \multirow[t]{2}{*}{ Z. angustifolia } & 'Linearis White' & 22 & AA & S I \\
\hline & A88C & 44 & AAAA & MA \\
\hline \multirow[t]{4}{*}{ Z. violacea } & 'Crimson Monarch' & 24 & VV & $\mathrm{BO}$ \\
\hline & 'Orange King' & 24 & VV & $\mathrm{BO}$ \\
\hline & 'Thumbelina Mini-Pink' & 24 & VV & $\mathrm{BO}$ \\
\hline & V86C & 48 & VVVV & MA \\
\hline \multirow[t]{2}{*}{ Z. marylandica } & $\mathrm{M} 1 \mathrm{C}$ & 46 & AAVV & M A \\
\hline & $\mathrm{M} 2 \mathrm{C}$ & 46 & AAVV & MA \\
\hline
\end{tabular}

${ }^{\mathrm{z}} \mathrm{A}=Z$. angustifolia $(n=11) ; \mathrm{V}=Z$. violacea $(n=12)$.

${ }^{\mathrm{y}} \mathrm{BO}=$ Bodger Seeds, Ltd., Lompoc, Calif.; MA = Univ. of Mass, Amherst; $\mathrm{SI}=$ Sutton and Sons (India) Pvt. Ltd., Calcutta, India. 
generations and were maintained by selfing. Henceforth, the parental material will be referred to by their genomic formulas instead of their chromosome numbers (Table 1).

Growing conditions. Plants were grown in glasshouses (Expts. 1,4 , and 5) or in an outdoor plot adjacent to the glasshouse range (Expts. 2 and 3). Temperature setpoints were 18/22C (heat/vent) during glasshouse experiments; actual glasshouse temperatures ranged from $16 \mathrm{C}$ minimum to maximum of about $40 \mathrm{C}$ for short durations during the summer. Plants were grown under natural daylengths (NDs) when the natural photoperiod was $>14 \mathrm{~h}$, and were otherwise grown under artificial long days (LDs) provided by supplementing ND with about $3 \mu \mathrm{mol} \cdot \mathrm{m}^{-1} \cdot \mathrm{s}^{-2}$ incandescent irradiation from 1600 to $2200 \mathrm{HR}$. Plants were fertilized at each irrigation with $20 \mathrm{~N} 4.3 \mathrm{P}-16.6 \mathrm{~K}$ at $200 \mathrm{mg} \mathrm{N} /$ liter.

$B C$, embryo development (Expt. 1). Line M $1 \mathrm{C}$ was crossed reciprocally with 'Linearis White', A88C, 'Orange King', and V86C. Emasculation and pollination procedures were reported previously (Boyle and Stimart, 1982). Ovaries were removed from florets at 14 days after pollination and were dissected under a stereomicroscope $(\times 32)$. Presence or absence of an embryo, and if present, the state of embryo development (normal or abnormal) were recorded for each tloret. Embryos were classified as abnormal if aborted or rudimentary (abnormally small). Embryos that were desiccated or necrotic were defined as aborted. The procedures described by Boyle et al. (1987) were used for identifying rudimentary embryos.

Morphology of BC, plants (Expt. 2). Four-week-old seedlings of $\mathrm{A} 88 \mathrm{C}, \mathrm{V} 86 \mathrm{C}, \mathrm{M} 1 \mathrm{C}$, and two $\mathrm{BC}_{1}$ families (female $\mathrm{M} 1 \mathrm{C} \times$ male V86C and female M $1 \mathrm{C} \times$ male A88C) were planted in an outdoor plot on 2 July 1988. Entries were arranged in a randomized complete block design with two blocks and one plot per block. Each plot consisted of 20 seedlings (four rows with five seedlings per row), with plants spaced on $30-\mathrm{cm}$ centers. Data were collected on plant height (from the soil surface to upper surface of the primary capitulum), leaf area (mean of two leaves collected from the second node below the primary capitulum), petal area of ray florets (mean of four fully expanded petals on the primary capitulum), number of ray florets (primary capitulum), and diameter of the primary capitulum. Leaf and ray petal areas were measured on a leaf area meter (LI-3000A; LI-COR, Lincoln, Neb.) Data were recorded on 2 and 4 Sept. 1988. To minimize border effects, data were collected on six plants in the inner two rows of each plot. One variable (number of ray florets per capitulum) was transformed $\left[\log _{10}(x+1)\right]$ due to variance heterogeneity. Means and standard deviations were calculated for each variable. Data were analyzed by the analysis of variance (ANOVA) procedure (SAS Inst., Cary, N. C.)

Fertility of $B C_{1}$ plants (Expt. 3). Flowering plants of $\mathrm{A} 88 \mathrm{C}$, V86C, M1C, and the two $\mathrm{BC}_{1}$ families were harvested from the border rows of the field plot described in Expt. 2. Flowering plants of 'Orange King' and 'Linearis White' were harvested from an adjacent plot. Stems with mature capitula were trimmed to $15 \mathrm{~cm}$, placed in water-filled containers, and brought to the laboratory. Pollen samples were obtained the following day. For each entry, pollen was collected from a minimum of six capitula, and then bulked to produce a composite pollen sample. Pollen viability was estimated by staining in $0.05 \%(\mathrm{w} / \mathrm{v})$ aniline blue in lactophenol (Arlington and La Cour, 1942). Intensely stained grains were scored as viable, whereas unstained or lightly stained grains were scored as inviable.

Senesced capitula were harvested from plants of the two $\mathrm{BC}_{1}$ families and line M1C that were growing in the field plot described earlier. Florets were removed from capitula and the ovaries were dissected under a stereomicroscope $(\times 32)$ to determine if embryos were present. About 50 capitula were examined for each entry.

Flower color of $B C_{1}$ plants (Expt. 4). Ray floret color for $\mathrm{Z}$. angustifolia (Linearis White' and A88C), Z. violacea ('Crimson Monarch', 'Orange King', 'Thumbelina Mini-Pink', and V86C), Z. marylandica (M1C and $\mathrm{M} 2 \mathrm{C}$ ), and three $\mathrm{BC}_{1}$ families was characterized qualitatively with the R.H.S. Colour Chart (Royal Horticultural Society, 1986). Fully expanded petals from glasshouse-grown plants were used to obtain single or interpolated values best describing color phenotype. Nominal descriptions of ray floret color were obtained from Kelly and Judd's (1976) dictionary of color names. Presence or absence of vacuolar pigments and carotenoid-containing chromoplasts was determined using visible light microscopy (Boyle and Stimart, 1989). A minimum of 10 petals were examined for each entry.

$B C_{l}$ seed emergence and within-family uniformity (Expt. 5). $\mathrm{B}_{1}$ seed was produced by crossing lines M1C and M2C (as maternal parents) with V86C. At harvest, shrivelled and lightweight seeds were retained in the seed lots to obtain unbiased estimates of seedling emergence. Seeds (480 per $\mathrm{BC}_{1}$ family) were sown in a peat-based germination medium that was maintained at $23 \mathrm{C}$ by bottom heat. The number of emerged seedlings was recorded at 14 days after sowing, and percent seed emergence was calculated for each $\mathrm{BC}_{1}$ family.

Five-week-old $\mathrm{BC}_{1}$ seedlings were transplanted into a $1.1 \times$ $14.0 \mathrm{~m}$ glasshouse ground bed on $12 \mathrm{Jan}$. 1987. The two $\mathrm{BC}_{1}$ families were arranged in a randomized complete block design, with two blocks and one plot per block. Each plot consisted of 105 plants (15 rows with seven plants per row), and plants were spaced on $18-\mathrm{cm}$ centers. Data were collected on 65 plants in the inner 13 rows of each plot. Plant height, leaf length, and width (maximum dimensions of one leaf collected from the second node below the primary capitulum), diameter of the primary capitulum, ray petal length and width (mean of two fully expanded petals on the primary capitulum), number of ray florets (primary capitulum), and days to flowering from seed sowing were recorded. The mean and coefficient of variation were calculated for each variable. A two-tailed $\mathrm{F}$ test was used to test for equal variances for the two $\mathrm{BC}_{1}$ families.

\section{Results and Discussion}

Experiment 1. Generally, backcrosses with Z. marylandica were more successful with $Z$. angustifolia and $Z$. violacea as autotetraploids than as diploids (Table 2). For crosses between $Z$. angustifolia (AA) and Z. marylandica, the percentage of florets with embryos was significantly greater with $Z$. angustifolia as the maternal parent as compared to the reciprocal cross. However, most embryos from crosses between $Z$. angustifolia (AA) and $Z$. marylandica were developmentally abnormal, regardless of crossing direction. Crosses between $Z$. angustifolia (AAAA) and $Z$. marylandica yielded similar results in both directions, with $64 \%-$ $65 \%$ of pollinated florets containing embryos and 9\%-10\% abnormal embryos. Reciprocal crosses between $\mathrm{Z}$. violacea $(\mathrm{VV})$ and $\mathrm{Z}$. marylandica yielded few embryos, regardless of crossing direction, and $22 \%$ of the embryos exhibited abnormalities. When $\mathrm{Z}$. violacea (VVVV) was backcrossed with Z. marylandica, embryo yields were more than 8 -fold higher and the percentage of abnormal embryos was lower with $Z$. rnarylandica as maternal parent rather than as pollen parent.

Bernström ( 1953) reported that few $\mathrm{BC}_{1}$ progeny were obtained when allotetraploid Lamium intermedium (= L. hybridum Vill.) was crossed reciprocally with its diploid ancestors, i.e., $L$. 
Table 2. Percent florets with embryos and percent abnormal embryos for backcrosses of allotetraploid Zinnia marylandica (AAVV) with diploid and autotetraploid forms of $Z$. angustifolia and Z. violacea.

\begin{tabular}{|c|c|c|c|}
\hline Cross (female $x$ male) & $\begin{array}{c}\text { Florets } \\
\text { pollinated (no.) }\end{array}$ & $\begin{array}{l}\text { Florets with } \\
\text { embryos }(\%)\end{array}$ & $\begin{array}{c}\text { Abnormal } \\
\text { embryos }(\%)^{z}\end{array}$ \\
\hline Z. marylandica $\times$ Z. angustifolia $(\mathrm{AA})^{y}$ & 300 & 3 & 100 \\
\hline Z. angustifolia (AA) $\times$ Z. marylandica & 302 & 28 & 78 \\
\hline Reciprocal differences & & $* * *$ & NS \\
\hline Z. marylandica $\times$ Z. angustifolia (AAAA) & 308 & 65 & 9 \\
\hline Z. angustifolia (AAAA) $\times Z$. marylandica & 304 & 64 & 10 \\
\hline Reciprocal differences & & NS & NS \\
\hline Z. marylandica $\times Z$. violacea (VV) & 288 & 0 & $-\cdots$ \\
\hline Z. violacea (VV) $\times$ Z. marylandica & 258 & 7 & 22 \\
\hline Reciprocal differences & & $* * *$ & --- \\
\hline Z. marylandica $\times$ Z. violacea (VVVV) & 233 & 69 & 1 \\
\hline Z. violacea (VVVV) $\times$ Z. marylandica & 268 & 8 & 45 \\
\hline Reciprocal differences & & $* * *$ & $* * *$ \\
\hline
\end{tabular}

${ }^{2}$ Number of aborted or rudimentary embryos/total number of embryos $(\times 100)$.

${ }^{y} \mathrm{~A}=\mathrm{Z}$. angustifolia $(n=11) ; \mathrm{V}=Z$. violacea $(n=12)$.

${ }^{\mathrm{Ns}}, * * *$ Nonsignificant or significant at $P<0.001$, respectively, by heterogeneity $x^{2}$ test.

Table 3. Expected chromosome numbers for embryos and endosperm obtained from backcrossing allotetraploid Zinnia marylandica (AAVV) with diploid and autotetraploid forms of the parental species Z. angustifolia and $Z$. violacea.

\begin{tabular}{lcc}
\hline \hline & \multicolumn{2}{c}{ Chromosome no. } \\
\cline { 2 - 3 } Cross (female $\times$ male) & $\begin{array}{c}\text { Embryo } \\
(2 n)\end{array}$ & $\begin{array}{c}\text { Endosperm } \\
(3 n)\end{array}$ \\
\hline Z. marylandica $\times$ Z. angustifolia (AA) & 34 & 57 \\
Z. angustifolia (AA) $\times$ Z. marylandica & 34 & 45 \\
Z. marylandica $\times$ Z. angustifolia (AAAA) & 45 & 68 \\
Z. angustifolia $(\mathrm{AAAA}) \times$ Z. marylandica & 45 & 67 \\
Z. marylandica $\times$ Z. violacea (VV) & 35 & 58 \\
Z. violacea (VV) $\times$ Z. marylandica & 35 & 47 \\
Z. marylandica $\times$ Z. violacea (VVVV) & 47 & 70 \\
Z violacea (VVVV) x Z. marylandica & 47 & 71
\end{tabular}

${ }^{\mathrm{z}} \mathrm{A}=\mathrm{Z}$. angustifolia $(n=11) ; \mathrm{V}=\mathrm{Z}$. violacea $(n=12)$.

amplexicaule L. and L. purpureum L. In contrast, numerous $\mathrm{BC}_{1}$ hybrids were obtained when autotetraploid $L$. amplexicaule was crossed reciprocally with $L$. intermedium, and when autotetraploid $L$. purpureum was used as a pollen parent in crosses with $L$. intermedium. Similar results were obtained in the current experiments: backcrosses with allotetraploid Z. marylandica were more successful when the parental species were autotetraploids rather than diploids (Table 2). Increasing the ploidy level of the parental material appears to be an effective technique for circumventing barriers in backcrosses with allopolyploids.

Zinnia produces a monosporic, eight-nucleate embryo sac of the Polygonum type (Maheswari Devi, 1963; Pullaiah, 1981). Double fertilization in Polygonum-type embryo sacs yields endosperm nuclei with two sets of maternal chromosomes and one set of paternal chromosomes, and zygotic nuclei with one set of maternal chromosomes and one set of paternal chromosomes. Since Z. marylandica and the parental species differ in chromosome number, reciprocal crosses would thus result in zygotes with identical chromosome numbers and endosperms with different chromosome numbers (Table 3). As a consequence, reciprocal crosses will exhibit differences in the ratios of chromosome numbers in the embryo, endosperm, and maternal tissue, and in gene dosage (Hadley and Openshaw, 1980; Stebbins, 1958). Reciprocal differences in the percentage of florets with embryos and the percentage of abnormal embryos may have resulted from differences in gene dosage and/or chromosome numbers (Table 2).

When attempting to cross two species differing in chromosome number, it is often recommended to utilize the species with the greater number of chromosomes as the maternal parent (Hadley and Openshaw, 1980; Stebbins, 1958). For three pairs of Zinnia backcrosses, however, higher yields of embryos were obtained when the species with fewer chromosomes was used as the maternal parent, and, for the fourth pair [Z. marylandica $\times Z$. angustifolia (AAAA)], there was no reciprocal difference in the percentage of florets with embryos (Table 2). These results demonstrate the importance of performing reciprocal crosses to maximize the probability of success in interspecific hybridization programs.

Experiment 2. Crosses between $Z$. marylandica $\mathrm{M} 1 \mathrm{C}$ and $Z$. angustifolia $\mathrm{A} 88 \mathrm{C}$ yielded $\mathrm{BC}_{1}$ plants that were intermediate between the two parents in capitulum diameter, resembled $\mathrm{A} 88 \mathrm{C}$ in ray petal area, resembled M1C in number of ray florets, and exceeded both parents with respect to plant height and leaf area (Table 4). $\mathrm{BC}_{1}$ progeny of $\mathrm{M} 1 \mathrm{C}$ and $Z$. violacea $V 86 C$ were intermediate between the two parents for all morphological characters that were examined. The coefficients of variation for the $\mathrm{BC}_{1}$ families were similar to the parental lines for most of the morphological characters.

Zinnia capitula that consist primarily or entirely of ray florets (double flowers) have the greatest ornamental value, whereas capitula with ray florets in a single whorl (single flowers) or a few whorls (semi-double flowers) have less ornamental value. Most modern-day cultivars of $Z$. violacea yield a high percentage of plants with double- and semi-double flowers. Cultivars of $\mathrm{Z}$. angustifolia, however, are single-flowered. Boyle and Stimart (1982) reported that $Z$. angustifolia $\times Z$. violacea allodiploids (AV) resembled the $Z$. angustifolia parent (AA) with respect to numbers of ray florets, even when the $Z$. violacea parent (VV) produced double flowers (> 100 ray florets per capitulum). In the current study, $\mathrm{BC}_{1}$ progeny of $Z$. marylandica and autotetraploid $Z$. violacea produced significantly more ray florets than $Z$. marylandica, but only half as many ray florets as autotetraploid $Z$. 
Table 4. Morphological characters of Zinnia angustifolia (Z.a.) A88C, Z. marylandica (Z.m.) M1C, Z. violacea (Z.v.) V86C, and two BC families.

\begin{tabular}{|c|c|c|c|c|c|c|c|c|c|c|c|}
\hline \multirow[b]{2}{*}{ Accession } & \multirow{2}{*}{$\begin{array}{l}\text { Genomic } \\
\text { formula }^{2}\end{array}$} & \multicolumn{2}{|c|}{ Plant ht (cm) } & \multicolumn{2}{|c|}{ Leaf area $\left(\mathrm{cm}^{2}\right)$} & \multicolumn{2}{|c|}{ Ray petal area $\left(\mathrm{cm}^{2}\right)$} & \multicolumn{2}{|c|}{ Ray petals (no.) } & \multicolumn{2}{|c|}{$\begin{array}{l}\text { Capitulum } \\
\text { diam }(\mathrm{cm})\end{array}$} \\
\hline & & Mean & $\mathrm{CV}$ & Mean & $\mathrm{CV}$ & Mean & $\mathrm{CV}$ & Mean & $\mathrm{CV}$ & Mean & $\mathrm{CV}$ \\
\hline Z. angustifolia $\mathrm{A} 88 \mathrm{C}$ & AAAA & $36.1 \mathrm{e}^{y}$ & 17.6 & $8.6 \mathrm{e}$ & 12.0 & $1.6 \mathrm{~d}$ & 11.0 & $10.1 \mathrm{~d}$ & 14.3 & $4.4 \mathrm{e}$ & $\overline{8.6}$ \\
\hline $\mathrm{BC}_{1}:$ Z.m. M1C $\times$ Z.a. A88C & AAAV & $52.0 \mathrm{c}$ & 6.4 & $22.0 \mathrm{c}$ & 16.0 & $1.8 \mathrm{~d}$ & 14.4 & $13.0 \mathrm{c}$ & 8.0 & $4.9 \mathrm{~d}$ & 6.4 \\
\hline Z. marylandica MIC & AAVV & $43.7 \mathrm{~d}$ & 15.5 & $15.7 \mathrm{~d}$ & 10.5 & $2.6 \mathrm{c}$ & 5.4 & $12.4 \mathrm{c}$ & 7.3 & $6.0 \mathrm{c}$ & 3.6 \\
\hline $\mathrm{BC}_{1}: Z . m . \mathrm{MIC} \times \mathrm{Z} . v . \mathrm{V} 86 \mathrm{C}$ & AVVV & $73.7 \mathrm{~b}$ & 4.1 & $53.1 \mathrm{~b}$ & 14.0 & $3.4 \mathrm{~b}$ & 28.1 & $16.4 \mathrm{~b}$ & 13.9 & $7.8 \mathrm{~b}$ & 9.9 \\
\hline Z. violacea $\mathrm{V} 86 \mathrm{C}$ & VVVV & $77.9 \mathrm{a}$ & 5.4 & $81.1 \mathrm{a}$ & 12.9 & $5.1 \mathrm{a}$ & 11.2 & $32.2 \mathrm{a}$ & 46.1 & $11.1 \mathrm{a}$ & 4.7 \\
\hline
\end{tabular}

${ }^{\overline{2}} \mathrm{~A}=$ Z. angustifolia $(n=11) ; \mathrm{V}=Z$. violacea $(n=12)$. Genomic formulas for the two $\mathrm{BC}_{1}$ families are expected values and not based on actual chromosome counts.

Mean separation within columns by Duncan's multiple range test, $P=0.05$.

Table 5. Stainability of pollen for Zinnia angustifolia (Z.a.) 'Linearis White' and A88C, Z. violacea (Z.v.) 'Orange King' and V86C, allotetraploid Z. marylandica (Z.m.) line $\mathrm{M} 2 \mathrm{C}$, and two $\mathrm{BC}_{1}$ families.

\begin{tabular}{lccc}
\hline \hline & $\begin{array}{c}\text { Genomic } \\
\text { formula }^{z}\end{array}$ & $\begin{array}{c}\text { Pollen grains } \\
\text { examined } \\
(\text { no. })\end{array}$ & $\begin{array}{c}\text { Stainable } \\
\text { pollen } \\
(\%)^{y}\end{array}$ \\
\hline Accession & AA & 1122 & 87.0 \\
Z.a. 'Linearis White' & AAAA & 973 & 63.6 \\
BC $:$ Z.m. M1C x Z.a. A88C & AAAV & 1329 & 33.5 \\
Z.m. M1C & AAVV & 912 & 53.1 \\
BC. $:$ Z.m. M1C $\times$ Z.v. V86C & AVVV & 988 & 0 \\
Z.v. 'Orange King' & VV & 1481 & 95.3 \\
Z.v. V86C & VVVV & 1036 & 27.2
\end{tabular}

${ }^{2} \mathrm{~A}=Z$. angustifolia $(n=11) ; \mathrm{V}=Z$. violacea $(n=12)$. Genomic formulas for the two $\mathrm{BC}_{1}$ families are expected values and not based on actual chromosome counts.

$\mathrm{Y}$, Stainability evaluated using aniline blue in lactophenol.

violacea (Table 4); these $\mathrm{BC}_{1}$ plants were generated using $\mathrm{Z}$. violacea cultivars with either semi-double (V86C) or double (Thumbelina Mini-Pink' and 'Crimson Giant') flowers, and a Z. angustifolia cultivar ('Linearis White' ) with single flowers. These results suggest that the $Z$. angustifolia genome exerts a dominant effect on the floral morphology of $Z$. marylandica, limiting the number of ray florets in capitula of $\mathrm{F}_{1}$ and $\mathrm{BC}_{1}$ hybrids.

Experiment 3. Pollen stainability varied substantially among the seven entries (Table 5). Zinnia marylandica $\mathrm{Ml} \mathrm{C}$ yielded about $50^{\prime}-\%$ stainable pollen. $\mathrm{BC}_{1}$ progeny of $\mathrm{M} 1 \mathrm{C}$ and $Z$. violacea V86C produced malformed pollen grains that were either unstained or lightly stained, whereas $\mathrm{BC}_{1}$ progeny of $\mathrm{M} 1 \mathrm{C}$ and $\mathrm{Z}$. angustifolia $\mathrm{A} 88 \mathrm{C}$ yielded about $33 \%$ darkly-stained pollen grains. Autotetraploid plants of Z. violacea (V86C) and Z. angustifolia (A88C) produced fewer stainable pollen grains than their diploid counterparts.

Field-grown plants of M1C yielded 30 to 75 plump seeds per capitulum. No embryos, however, were observed in capitula collected from any field-grown $\mathrm{BC}_{1}$ plants.

Bumblebees (Bombus spp.) and honeybees (Apis mellifera) were frequently observed on and near Zinnia capitula of fieldgrown plants. These insects spent less time on flowers of the $\mathrm{BC}_{1}$ plants compared to flowers of Z. angustifolia, Z. marylandica, and $Z$. violacea. Social bees such as bumblebees and honeybees search for flowers that yield the greatest quantities of pollen and nectar (Richards, 1986; Widrlechner and Senechal, 1992). Brief visitation times on $\mathrm{BC}_{1}$ plants may be due to insufficient pollen and/or nectar, which may have been partially responsible for lack of seed production by field-grown $\mathrm{BC}_{1}$ plants.
Experiment 4. Ray florets of Z. angustifolia 'Linearis White' and A88C were devoid of chromoplasts and vacuolar pigmentation (Table 6). Pigmentation of Z. violacea ray florets consisted of chromoplasts in the cytoplasm, pink to red flavonoids in the vacuoles, or both. Vacuolar pigmentation was present and chromoplasts were absent in ray florets of $Z$. marylandica lines M $1 \mathrm{C}$ and $\mathrm{M} 2 \mathrm{C}$, and $\mathrm{BC}_{1}$ hybrids obtained from crossing $Z$. marylandica $\mathrm{M} 1 \mathrm{C}$ with either $Z$. angustfolia $\mathrm{A} 88 \mathrm{C}$ or $Z$. violacea V86C. $\mathrm{BC}_{1}$ progeny obtained from crossing $Z$. marylandica $M 2 C$ with $\mathrm{Z}$. violacea V86C produced both vacuolar pigmentation and chromoplasts in their ray florets, yielding a distinctive petal color (deep yellowish pink) not found in other $\mathrm{BC}_{1}$ hybrids.

Diversity of ray floret color in Z. violacea is due primarily to variation in the amount of carotenoids and flavonoids that accumulate in epidermal cells (Boyle and Stimart, 1989). Carotenoids are necessary to achieve vivid red ('Crimson Monarch'), strong orange (Orange King' ), and brilliant yellow (V86C) floral colors in Z. violacea (Table 6). Carotenoids are not present in ray florets of $Z$. angustifolia, nor are they found in allodiploid (AV) or allotetraploid (AAVV) hybrids of $Z$. angustifolia and Z. violacea (Table 6; Boyle and Stimart, 1989), thus limiting the range of floral colors that are possible within these taxa. $\mathrm{BC}_{1}$ progeny of $Z$. marylandica and $Z$. violacea $\mathrm{V} 86 \mathrm{C}$ exhibited differences in floral pigmentation, with carotenoids absent in $\mathrm{BC}_{1}$ plants derived from $Z$. marylandica $\mathrm{M} 1 \mathrm{C}$ but present in $\mathrm{BC}_{1}$ plants derived from $Z$. marylandica $\mathrm{M} 2 \mathrm{C}$ (Table 6). These differences are likely due to gene dosage effects. Presence of carotenoids in $Z$. violacea ray florets is controlled by a recessive gene (ca) (Boyle and Stimart, 1988). BC $\mathrm{B}_{1}$ progeny of $\mathrm{Z}$. marylandica $\mathrm{M} 2 \mathrm{C}$ and $Z$. violacea $\mathrm{V} 86$ contained three $Z$. violacea genomes (AVVV), all of which coded for presence of ray floret carotenoids ( $c a)$; two genomes were from V86C ( $c a c a)$ and one genome came from 'Crimson Monarch' ( $\mathrm{ca} \mathrm{ca}$ ) via $Z$. marylandica ( ca ca). $\mathrm{BC}_{1}$ progeny of Z. marylandica M1C and Z. violacea V86, however, contained only two $Z$. violacea genomes coding for presence of ray floret carotenoids, both of which came from V86C ( $c$ a $\mathrm{ca}$ ); the third $Z$. violacea genome came from 'Thumbelina Mini-Pink' ( $\left.\mathrm{Ca}_{-}\right)$via Z. marylandica $(\mathrm{Ca} \mathrm{Ca})$. Presence of carotenoids in $\mathrm{BC}_{1}$ hybrids of $Z$. marylandica and $\mathrm{Z}$. violacea will likely extend the range of ray floret color beyond that observed within lines of $Z$. marylandica.

Experiment 5. Percent seed emergence was $49 \%$ for the cross $\mathrm{M} 1 \mathrm{C} \times \mathrm{V} 86 \mathrm{C}$, but was significantly higher $(57 \%)$ for the cross $\mathrm{M} 2 \mathrm{C} \times \mathrm{V} 86 \mathrm{C}(\mathrm{P}<0.05) . \mathrm{BC}_{1}$ plants of M1C $\times$ V86C were less variable in plant height, leaf dimensions, capitulum diameter, and ray petal length compared to $\mathrm{BC}_{1}$ plants of $\mathrm{M} 2 \mathrm{C} \times \mathrm{V} 86 \mathrm{C}$ (Table 7). The two $\mathrm{BC}_{1}$ families displayed similar variances for ray petal width, ray petal number, and days to flowering.

Relatively uniform $\mathrm{BC}_{1}$ families were generated in this study 
Table 6. Color and pigment location in ray floret petals of Zinnia angustfolia (Z.a.), Z. violacea (Z.v.), Z. marylandica (Z.m.), and $\mathrm{BC}_{1}$ interspecific hybrids.

\begin{tabular}{|c|c|c|c|c|c|}
\hline \multirow[b]{2}{*}{ Accession } & \multirow{2}{*}{$\begin{array}{l}\text { Genomic } \\
\text { formula }^{2}\end{array}$} & \multirow{2}{*}{$\begin{array}{l}\text { Ray floret } \\
\text { color }^{y}\end{array}$} & \multirow{2}{*}{$\begin{array}{l}\text { RHS } \\
\text { no. }\end{array}$} & \multicolumn{2}{|c|}{ Pigment location } \\
\hline & & & & Plastid $^{w}$ & Vacuole $^{y}$ \\
\hline Z.a. 'Linearis White' & $\mathrm{AA}$ & White & $155 \mathrm{~A}$ & - & - \\
\hline Z.a. $\mathrm{A} 88 \mathrm{C}$ & AAAA & White & $155 \mathrm{~A}$ & - & - \\
\hline Z.v. 'Crimson Monarch' & VV & Vivid red & $45 \mathrm{~A}$ & + & +++ \\
\hline Z.v. 'Orange King' & VV & Strong orange & $28 \mathrm{~B}$ & + & ++ \\
\hline Z.v. 'Thumbelina Mini-Pink' & VV & Strong purplish pink & $61 \mathrm{D}$ & - & ++ \\
\hline Z.v. V86C & VVVV & Brilliant yellow & $13 \mathrm{~A}$ & + & - \\
\hline Z.m. MIC & AAVV & Vivid purplish red & $58 \mathrm{~B}$ & - & ++ \\
\hline Z.m. M2C & AAVV & Moderate purplish red & $52 \mathrm{~A}$ & - & $+t$ \\
\hline $\mathrm{BC}_{1}: Z . m . \mathrm{M} 1 \mathrm{C} \times Z . a . \mathrm{A} 88 \mathrm{C}$ & AAAV & Pale pink & $62 \mathrm{D}$ & - & + \\
\hline $\mathrm{BC}_{1}: Z . m . \mathrm{M} 1 \mathrm{C} \times Z . v . \mathrm{V} 86 \mathrm{C}$ & AVVV & Deep purplish pink & $62 \mathrm{~A}$ & - & ++ \\
\hline $\mathrm{BC}_{1}: Z . m . \mathrm{M} 2 \mathrm{C} \times Z . v . \mathrm{V} 86 \mathrm{C}$ & AVVV & Deep yellowish pink & $43 \mathrm{C}$ & + & ++ \\
\hline
\end{tabular}

${ }^{2} \mathrm{~A}=\mathrm{Z}$. angustifolia $(n=11) ; \mathrm{V}=\mathrm{Z}$. violacea $(n=12)$. Genomic formulas for the $\mathrm{BC}_{1}$ families are expected values and not based on actual chromosome counts.

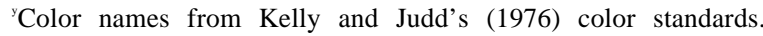

${ }^{x}$ Royal Horticultural Society (RHS) Colour Chart numbers based on comparisons with fully expanded petals. "Presence $(+)$ or absence $(-)$ of chromoplasts in upper epidermal cells.

'Intense $(+++)$, moderate $(++)$. or weak $(+)$ pigmentation in upper epidermal cells, or pigmentation absent $(-)$.

(Tables 4 and 7), and were attainable due to the true-breeding, allotetraploid constitution of Z. marylandica (Terry -Lewandowski et al., 1984). Greater phenotypic uniformity maybe possible by utilizing elite, highly uniform inbred lines of Z. angustifolia and $\mathrm{Z}$. violacea for $\mathrm{BC}_{1}$ seed production. An effective method for preventing selfing in the maternal parent is also necessary for producing uniform $\mathrm{BC}_{1}$ families. In the current experiments, selfing was prevented by emasculating capitula of $Z$. marylandica before crossing (Boyle and Stimart, 1982). This procedure is laborious and not practical for producing large quantities of $\mathrm{BC}_{1}$ seed. Commercial firms produce $\mathrm{F}$, hybrid seed of $Z$. violacea by using apetalous, malesterile (femina) plants as maternal parents (Reimann-Philipp, 1983). Attempts to transfer the femina trait from $Z$. violacea to Z. marylandica have been unsuccessful, probably due to recessiveness of this character in the presence of the Z. angustifolia genome (T.H. Boyle, unpublished data). An alternative method for producing $\mathrm{BC}_{1}$ seed would be to use clonally propagated, self-incompatible plants as maternal parents, as has been done for producing $\mathrm{F}$, seed in several other Composite species (Reimann-Philipp, 1983). Sporophytic self-incompatibility (SI) is present in Z. angustifolia and Z. violacea (Boyle and Stimart, 1986; Samaha and Boyle, 1989), and is expressed in some Z. marylandica clones (T.H. Boyle, unpublished data).

These experiments demonstrate that seed-generated $\mathrm{BC}_{1}$ prog- eny can be produced from crossing Z. marylandica to autotetraploid forms of $Z$. angustifolia and $Z$. violacea. $\mathrm{B} \mathrm{C}_{1}$ plants from crosses between autotetraploid $Z$. angustifolia and $Z$. marylandica yielded smaller, less showy capitula than those of $Z$. marylandica (Table 4). In contrast, $\mathrm{BC}_{1}$ plants obtained from crossing $\mathrm{Z}$. marylandica with autotetraploid $Z$. violacea were highly ornamental, with larger capitula, more ray florets, and a greater diversity of floral pigments than Z. marylandica (Tables 4 and 6). These plants may have commercial potential not only for their ornamental value, but also for their infertility $\mathrm{y}$, therefore providing a high degree of proprietary protection for seed producers. Further exploitation of Z. marylandica germplasm is likely to yield additional material with ornamental value.

\section{Literature Cited}

Andersen, K. 1971. The behavior of powdery mildew conidia (Erysiphe cichoracearum) on the leaves of resistant and susceptible species of Zinnia. MS thesis. Pennsylvania State Univ., University Park.

Bernstrom, P. 1953. Increased crossability in Lamium after chromosome doubling. Hereditas 39:241-256.

Boyle, T.H. and D.P. Stimart. 1982. Interspecific hybrids of Zinnia elegans Jacq. and Z. angustifolia HBK: Embryology, morphology and powdery mildew resistance. Euphytica 31:857-867.

Table 7. Influence of Z. marylandica genotype on morphology, flowering, and uniformity of two $\mathrm{BC}_{1}$ families.

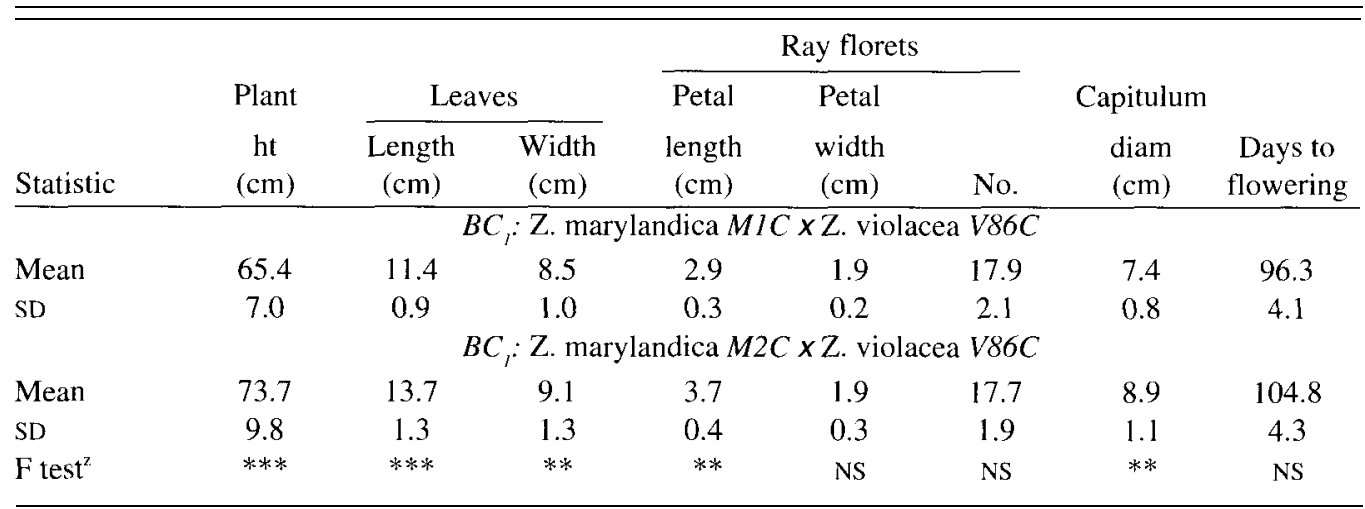

${ }^{2}$ Two-tailed $\mathrm{F}$ test for equal variances,

ss, **, ***Nonsignificant or significant at $P<0.01$ or 0.001 , respectively. 
Boyle, T.H. and D.P. Stimart. 1986. Self-incompatibility and interspecific incompatibility: Relationships in intra- and interspecific crosses of Zinnia elegans Jacq. and Z. angustifolia HBK (Composite). Theor. Appl. Genet. 73:305-315.

Boyle, T.H. and D.P. Stimart. 1988. Inheritance of ray floret color in Zinnia angustifolia HBK and Z. elegans Jacq. J. Hered. 79:289-293.

Boyle, T.H. and D.P. Stimart. 1989. Anatomical and biochemical factors determining ray floret color of Zinnia angustifolia, Z. elegans, and their interspecific hybrids. J. Amer. Soc. Hort. Sci. 114:499-505.

Boyle, T. H,, D.P. Stimart, and G.R. Bauchan. 1987. Influence of Zinnia angustifolia HBK genotype on embryonic and vegetative development of $Z$. angustifolia $\times$ Z. elegans Jacq. interspecific hybrids. Theor. Appl. Genet. 73:716-723.

Darlington, C.D. and L.F. La Cour. 1942. The handling of chromosomes. Macmillan, New York.

Hadley, H.H. and S.J. Openshaw. 1980. Interspecific and intergeneric hybridization, p. 133-1 59. In: W.R. Fehr and H.H. Hadley (eds.). Hybridization of crop plants. Amer. Soc. Agron., Crop Sci. Soc. Amer., Madison, Wis,

Jones, J.J. and D.L. Strider. 1979. Susceptibility of zinnia cultivars to bacterial leaf spot caused by Xanthomonas nigromaculans f. sp. zinniae. Plant Dis. Rpt. 63:449-453.

Kelly, K.L. and D.B. Judd. 1976. Color: Universal language and dictionary of names. Natl. Bur. Standards Spec. Bul. 440. U.S. Govt. Printing Off., Wash., D.C.

Lipschutz, L. 1965. The resistance of Zinnia species to Alternaria zinniae Pape. MS thesis. Pennsylvania State Univ., University Park.

Maheswari Devi, H. 1963. Embryological studies in Composite. 4. Heliantheae. Proc. Indian Acad. Sci. Ser. B. 58:274-290.

McVaugh, R. 1984. Flora novo-galiciana: A descriptive account of the vascular plants of western Mexico. vol. 12. Composite. Univ. of Mich., Ann Arbor.

Pullaiah, T. 1981. Studies in the embryology of Heliantheae (Composite). Plant Systematic Evolution 137:203-214.

Reimann-Philipp, R. 1983. Heterosis in ornamentals, p. 234-259. In: R. Frankel (ed.). Heterosis: Reappraisal of theory and practice, Monographs on theoretical and applied genetics 6. Springer-Verlag, Berlin.

Richards, A.J. 1986. Plant breeding systems. George Allen and Unwin, London.

Royal Horticultural Society, 1986. R.H.S. colour chart, Royal Hort. Soc., London, and Flower Council of Holland, Leiden, The Netherlands,

Samaha, R.R. and T.H. Boyle. 1989. Self-incompatibility of Zinnia angustifolia HBK (Composite): II. Genetics. J. Hered. 80:368-372.

SAS Institute. 1985. SAS/STAT guide for personal computers. version 6. SAS Inst., Cary, N.C.

Spooner, D. M., D.P. Stimart, and T.H. Boyle. 1991. Zinnia marylandica (Asteraceae: Heliantheae), a new disease-resistant ornamental hybrid. Brittonia 43:7-10.

Stebbins, G.L. 1958. The inviability, weakness, and sterility of interspecific hybrids, p. 147-215. In: M. Demerec (ed.). Advances in genetics. vol. IX. Academic Press, New York,

Terry -Lewandowski, V.M. and D.P. Stimart. 1983. Multiple resistance in induced amphiploids of Zinnia elegans and Z. angustifolia to three major pathogens. Plant Dis. 67: 1387-1 389,

Terry-Lewandowski, V.M., G.R. Bauchan, and D.P. Stimart. 1984. Cytology and breeding behavior of interspecific hybrids and induced amphiploids of Zinnia elegans and Zinnia angustifolia. Can. J. Genet. Cytol. 26.40-45.

Torres, A.M. 1963. Taxonomy of Zinnia. Brittonia 15: 1-25.

Widrlechner, M.P. and N.P. Senechal. 1992, Relationships between nectar production and honey bee preference. Bee World 73:11 9-1 27. 